\title{
Isolation, characterization, activity test and molecular identification of thermophilic bacteria producing proteases from Dolok Tinggi Raja Natural Hot Springs, North Sumatra, Indonesia
}

\author{
EDY FACHRIAL ${ }^{1}$, VISENSIUS KRISDIANILO ${ }^{2}$, HARMILENI ${ }^{3}$, I NYOMAN EHRICH LISTER ${ }^{4}$, \\ TITANIA T. NUGROHO ${ }^{5}$, SARYONO, \\ ${ }^{1}$ Laboratory of Molecular Biology, Faculty of Medicine, Universitas Prima Indonesia. Jl. Belanga No. 1, Medan 20118, North Sumatra, Indonesia \\ ${ }^{2}$ Graduate Program of Biomedical Sciences, Faculty of Medicine, Universitas Prima Indonesia. Jl. Belanga No. 1, Medan 20118, North Sumatra, \\ Indonesia \\ ${ }^{3}$ Politeknik Teknologi Kimia Industri. Jl. Medan Tenggara No. 7, Medan 20228, North Sumatra, Indonesia \\ ${ }^{4}$ Faculty of Medicine, Universitas Prima Indonesia. J1. Belanga No. 1, Medan 20118, North Sumatra, Indonesia \\ ${ }^{5}$ Department of Chemistry, Universitas Riau. J1. Bina Widya Km 12,5, Simpang Baru, Pekanbaru 28293, Riau, Indonesia, \\ Tel.: +62-761-63273, `email: saryono@lecturer.unri.ac.id
}

Manuscript received: 23 January 2021. Revision accepted: 9 March 2021

\begin{abstract}
Fachrial E, Krisdianilo V, Harmileni, Lister INE, Nugroho TT, Saryono. 2021. Isolation, characterization, activity test and molecular identification of thermophilic bacteria producing proteases from Dolok Tinggi Raja Natural Hot Springs, North Sumatra, Indonesia. Biodiversitas 22: 1725-1732. Proteases are complex enzymes that can be applied in both commercial products and physiological fields. This enzyme accelerates the breakdown of peptide bonds in polypeptides and proteins using hydrolysis reactions, transforming them into simpler bonds. In recent years, the demand for protease enzymes in Indonesia is still dependent on imported products, and there has also been an increase in their use. This is because there are many advantages in terms of efficiency, environmental friendliness, and its ability to catalyze a reaction without by-products. Proteases dominate the enzyme market with a total of $70 \%$ sales. Furthermore, they are manufactured from thermophilic bacteria as a solution to the problem of enzyme use in industries, where enzymes are easily damaged at high temperatures. The thermophilic protease enzyme can be found in thermophilic microorganisms living in extreme temperatures such as hot springs. There are lots of mountainous areas in North Sumatra Province, Indonesia with many hot springs. For example, the Dolok Tinggi Raja Natural Hot Springs of Simalungun District which has a water temperature of $50^{\circ} \mathrm{C}$ with a $\mathrm{pH}$ of about 6 , the potential of which still needs to be explored. This study aims to isolate and determine the activity and molecular structure of thermophilic bacteria producing protease in Dolok Tinggi Raja Natural Hot Springs. Protease activity was determined based on the formation of clear zones in Skim Milk Agar medium. In addition, a total of 20 isolates were successfully obtained from sediment and water. Each was tested biochemically and morphologically, where 19 isolates had the activity of proteases, with the highest in isolate UTMTR VK S9 of $23.67 \mathrm{U} / \mathrm{mL}$. Molecular identification was performed by the amplification of 16SrRNA gene based on BLAST and phylogenic analysis with MEGA X. Phylogenic results showed that isolate UTMTR VK S9 possessed similarities to Bacillus paralicheniformis strain A30103. Meanwhile, more research is required to purify enzymes for application in the industrial world.
\end{abstract}

Keywords: Bacteria, enzymes, molecular identification, protease, thermophilic

\section{INTRODUCTION}

The emergence of civilization and the rapid development of science enabled man to utilize various elements and organisms for human purposes, such as enzymes and microorganisms in manufacturing products on a high-quality industrial scale. Some enzymes that have been widely used in biotechnology processes include lipases, proteases, amylases and catalases (Baltaci et al. 2017). Proteases are complex enzymes that can be applied in commercial products or physiological fields. They accelerate the breakdown of peptide bonds in polypeptides and proteins using hydrolysis reactions, thereby making it a simpler bond (Baehaki et al. 2019).

In recent years, the demand for protease enzymes in Indonesia has been dependent on imported products, and there has also been an increase in their use. This is because there are many advantages in terms of efficiency, environmental friendliness, and its ability to catalyze a reaction with no by-products. Protease enzymes still dominate the enzyme market with a total of $70 \%$ sales (Rao et al. 1998). It is an extracellular enzyme synthesized within the cell and transported outside the cell (Martins 2006; Hamdani et al. 2019). Furthermore, proteases are widely used in biotechnology, leather industry, pharmaceuticals, food and beverage processing, meat auction and brewing industry (Kumar 1999; Gupta et al. 2002).

The industrial utilization of enzymes is constrained because this enzyme is unstable at high temperatures. Therefore, the stable form is obtained from microorganisms or bacteria living in extreme or high temperatures. They are isolated from thermophilic bacteria, which develop at high temperatures of about $45-70^{\circ} \mathrm{C}$. Furthermore, they possess an advantage over bacteria where their proteins function at 
high temperatures, where other enzymes will be damaged. These thermophilic bacteria grow and survive in hightemperature areas such as volcanic craters and hot springs (Nascimento and Martins 2004).

In the Dolok Tinggi Raja Natural Hot Springs, Simalungun District, North Sumatra Province, Indonesia, there are hot springs that have not been widely used to meet the need for enzymes and there may also be thermophilic bacteria that synthesize proteases. This study aims to isolate and determine the activity and molecular structure of thermophilic bacteria producing protease in Dolok Tinggi Raja Natural Hot Springs.

\section{MATERIALS AND METHODS}

\section{Study site}

This research was conducted in the Molecular Biology Laboratory, Faculty of Medicine, Universitas Prima Indonesia, Medan, Indonesia, with the sampling location at the Dolok Tinggi Raja Natural Hot Springs, Simalungun District, North Sumatra Province, Indonesia (Figure 1). Geographically, the Dolok Tinggi Raja is at $3^{\circ} 3^{\prime} 30^{\prime \prime} \mathrm{N}$ and $98^{\circ} 30^{\prime} 49^{\prime \prime} \mathrm{E}$. The research was conducted from December 2019 to March 2020.

\section{Sampling procedure}

Hot water sampling at the Dolok Tinggi Raja Natural Hot Springs was performed at a depth of approximately 1-2 meters (Figure 2). First, the temperature of hot water was measured using a thermometer, as well as the $\mathrm{pH}$ using a $\mathrm{pH}$ meter. Afterward, the results were recorded, and hot water samples were taken using a $25-50 \mathrm{~mL}$ plastic tube. Approximately 5-10 grams of sediment was also obtained, using Ekman Grab. Samples were stored in the icebox to keep the temperature stable on the way to the laboratory.

\section{Sample isolation}

Samples of hot water from the hot spring where placed in the broth nutrient medium for breeding. First, the sample was homogenized and then $1 \mathrm{~mL}$ was poured into the broth nutrient medium. This was followed by incubation at a temperature of $50^{\circ} \mathrm{C}$ or the corresponding temperature of the hot spring for 24 to 48 hours

Purification of microorganisms was performed using nutrient agar medium (NA). This involved culturing the nutrient broth, and scratching on the nutrient medium. This was done to incubate nutrients at a temperature adjusted to that of the hot spring for 24 hours, after which the growth of the colony of microorganisms was observed.

\section{Macroscopic and microscopic identification}

Macroscopic identification was performed by observing the shape of the colony, as well as the size, periphery, color, surface, and consistency in the isolated medium. Microscopic identification of microbes was done by coloring, namely by taking colonies of bacteria using ose, placing in glass objects and fixated using fire Bunsen burner. Coloring the bacteria was done using violet gentian reagents of about 2-3 drops. After a 1 minute delay, it was rinsed in running water, and 2-3 drops of Lugol/iodine added. After 1 minute, it was washed in running water, $96 \%$ alcohol, followed by another 30-second delay, and rinsed using running water again. After adequate drying, 23 drops of safranin were added and rinsed with running water after 10 seconds, and dried. Furthermore, colored bacteria were observed under a microscope at an enlargement of 1000x with the addition of immersion oil. The shape of bacterial cells and their color were then observed (Prescot et al. 1990).

\section{Biochemical characterization \\ Test Triple Sugar Iron Agar (TSIA)}

Carbohydrate fermentation with Triple Sugar Iron Agar medium test was performed by streaking the medium with isolated bacteria on Triple Sugar Iron Agar medium's surface. The middle of the medium was also punctured and placed in incubation at a temperature of $50^{\circ} \mathrm{C}$ for $24-48$ hours. Afterward, the medium was observed to ascertain any changes. Triple Sugar Iron Agar test is positive when the medium color changes to orange or yellow. It is also positive when $\mathrm{H}_{2} \mathrm{~S}$ is formed which is characterized by black coloration in the medium. The presence of gas is characterized by the formation of cavities at the bottom (Baehaki et al. 2019).

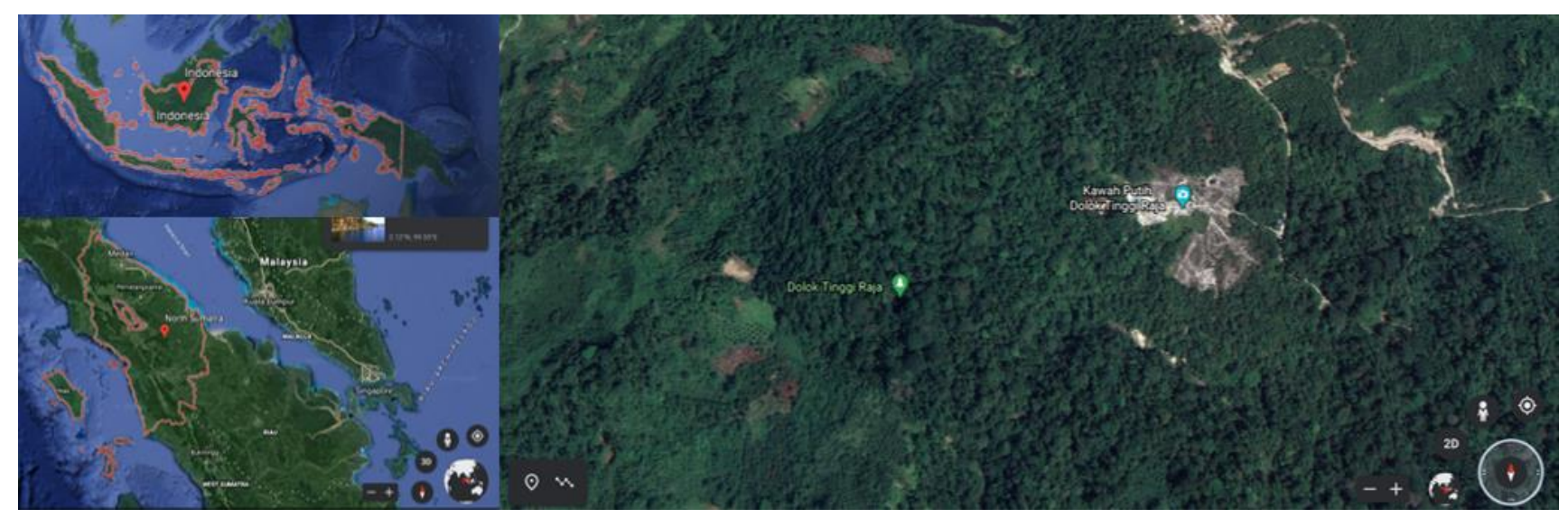

Figure 1. Location of natural hot springs Dolok Tinggi Raja, Simalungun District, North Sumatra Province, Indonesia 


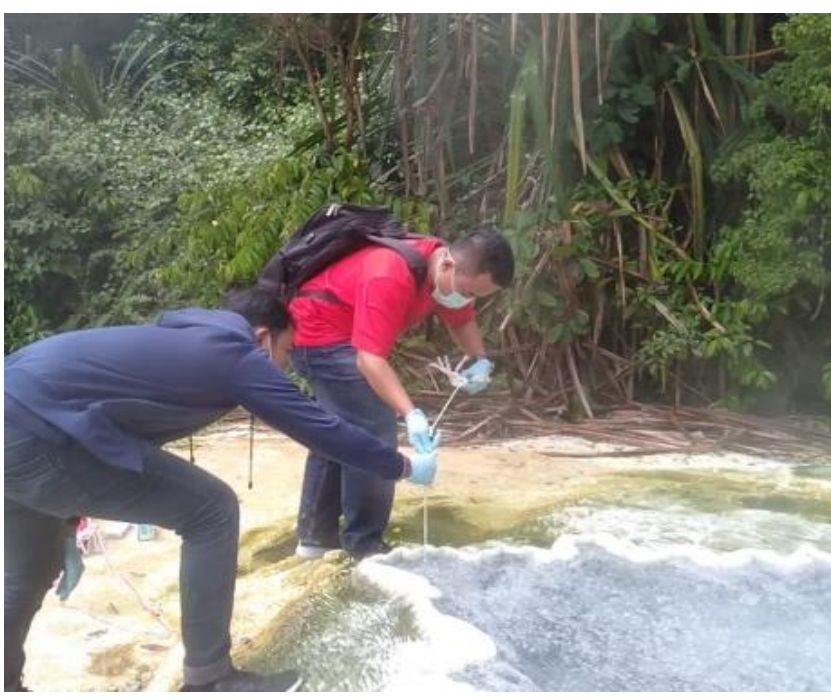

Figure 2. Sampling in natural hot springs of Dolok Tinggi Raja, Simalungun District, North Sumatra Province, Indonesia

\section{Simon citrate test}

Simon citrate test was carried out by obtaining bacterial suspensions. A scratch was then made on Simon's citrate medium in zig-zag format. Furthermore, incubation occurred at a temperature of $50^{\circ} \mathrm{C}$ for $18-24$ hours. A change in color from green to blue indicates a positive result (Tille 2013).

\section{Gelatin test}

Gelatinase test involved the inoculation of isolated bacteria by streaking perpendicularly using an ose needle on the side of gelatin medium, and incubated for 5 days at a temperature of $50^{\circ} \mathrm{C}$. Afterward, the medium culture was stored in the refrigerator for 15 minutes. A positive gelatinase test is characterized by a medium form that remains liquid, although it has been stored in the refrigerator.

\section{Motility test}

Motility test was performed by inoculation of isolated bacteria by piercing straight ose containing bacteria in sulfide indole motility medium. Afterward, the medium was incubated at $50^{\circ} \mathrm{C}$ for $24-48$ hours. The result of motility in bacteria is characterized by traces of bacterial movement (Baehaki et al. 2019).

\section{Screening of protease enzyme-producing microbes Enzyme protease test}

The activity of protease enzymes was observed using Skim Milk Agar. Microbes were observed during protease activity in the medium and were incubated at a temperature of $50^{\circ} \mathrm{C}$ for $24-72$ hours. Protease activity is characterized by forming transparent zones around the colony of microorganisms (Uyar et al. 2011; Hanan 2012).

\section{Protease production}

A total of $1 \mathrm{~mL}$ isolate of proteolytic bacteria was selected from the protease test results, inoculated into the
$20 \mathrm{~mL}$ liquid medium and incubated at a temperature of $50^{\circ} \mathrm{C}$ for 48 hours. Crude enzymes were obtained by evaluating the medium at a speed of $6000 \mathrm{rpm}$ for 20 minutes at room temperature, where the supernatant obtained was a crude protease (Vermelho 2013).

\section{Protease enzyme activity testing 19 isolates}

In this study, the activity of enzymes was tested by taking a maximum of $0.5 \mathrm{~mL}$ of substrate (Bovine Serum Albumin $300 \mu \mathrm{g} / \mathrm{mL}$ ), which was added to the mixture of phosphate buffer of $0.5 \mathrm{~mL}$ enzyme solution of $0.5 \mathrm{~mL}$ incubated at room temperature for 5 minutes. The mixture was further incubated at $50^{\circ} \mathrm{C}$ for 10 minutes. Afterward, it was placed in the refrigerator at a temperature of $5^{\circ} \mathrm{C}$ with $0.5 \mathrm{~mL}$ Trichloroacetic Acid $0.4 \mathrm{M}$ added to stop the enzymatic reaction (Alrumman 2018).

The PCR (Polymerase Chain Reaction) mixture was placed into a PCR machine with the setting of an initial denaturation process of $96^{\circ} \mathrm{C}$ for 5 minutes, followed by a denaturation process of 30 cycles at a temperature of $96^{\circ} \mathrm{C}$ for 30 seconds. Afterward, the annealing process was performed at a temperature of $55^{\circ} \mathrm{C}$ for 30 seconds, and lengthening the strands at $72^{\circ} \mathrm{C}$ for 1 minute. After 30 cycles, the final extension was at $72^{\circ} \mathrm{C}$ for 7 minutes. PCR amplification results underwent electrophoresis in agarose gel $(1.5 \%)$ in a buffer, visualized by coloring with Gel Red and analyzed with Gel Documentation. Amplification results were sorted using an automatic DNA sequence (ABI PRISM 3130 Genetic Analyzer) to determine the order of the DNA strands. The strand data obtained was combined with trimming data and assembled using BioEdit program (http://www.mbio.ncsu.edu/BioEdit/bioedit.html).

Meanwhile, to view taxons/species with the largest and closest molecular similarities, use the BLAST program, data listed on GenBank, and devices from the NCBI/National Center for Biotechnology Information (http://www.ncbi.nlm.nih).gov/BLAST/). To see phylogenetic trees, first align sequences from BLAST search with DNA strand data obtained using clusterW, then phylogenetic analysis using MEGAX program (Kumar et al. 2018; Fachrial et al. 2020).

\section{RESULTS AND DISCUSSION}

\section{Bacterial isolation}

The results of isolation of thermophilic bacteria in Dolok Tinggi Raja Natural Hot Springs obtained 20 isolates. 10 originated from water and the other 10 were derived from the hot spring sediment.

\section{Macroscopic and microscopic bacteria}

Isolate was further examined to ascertain the forms of bacterial colonies. The circular form was dominant, with the edges of dominant colonies filamentous with flat elevation, while the color of the colony was predominantly creamy (Table 1; Figure 3). Macroscopic bacterial examination aims to physically distinguish the type of bacteria based on the shape edges, surface, and color of the bacterial colony. 
Microscopic examination was performed as an initial step of bacterial identification. This microscopic examination involved Gram staining with reagents such as gentian violet, iodine or Lugol, $96 \%$ alcohol and safranin. The Gram staining results in this study obtained Gram (+) Basil for most bacteria, while there were only 2 isolates that were Gram (-) Basil, as shown in Table 2.

This Gram staining acts as a differentiator of the bacteria type based on the structure of its cell walls (Figure 4). These walls in Gram-positive bacteria have thick peptidoglycan, while in Gram-negative bacteria there is a thick lipid layer. When the gentian violet dye was added either Gram-positive or negative bacteria will absorb all the substance of color. However, when given alcohol Gramnegative bacteria will fade because it is majorly composed of lipids. When given safranin dye the Gram-negative will absorb the color substance from safranin therefore Gramnegative will be red. In addition, Gram-positive bacteria will still maintain violet, due to the thick layer of peptidoglycan on the cell walls of these bacteria (Baehaki et al. 2019).

\section{Biochemical characterization}

The test results from the biochemical identification of bacteria were all negative for gelatin, catalase, motility and citrate. However, for Triple Sugar Iron Agar test the results were entirely positive with predominantly red and yellow results (MK) results, as shown in Table 3. The results of motility test obtained negative results, which signified that the bacteria cannot move. Most of the bacteria that are spiral-dredged and basil are motile, while the cochlearshaped ones are immotile. This is because the spiraldredged bacteria or basil have a whip-like propulsion device called flagella, enabling them to move around the watery environment (Baehaki et al. 2019).

There was a negative result in the citrate test isolate, as the green color of the medium did not change. This citrate test uses Simon citrate medium, and when bacteria utilize citrate the acidic content in the medium will be lost. This increases the $\mathrm{pH}$ which changes the color of the medium from green to blue. This color change indicates the presence of bacteria capable of using citrate as a source of carbon (Baehaki et al. 2019).

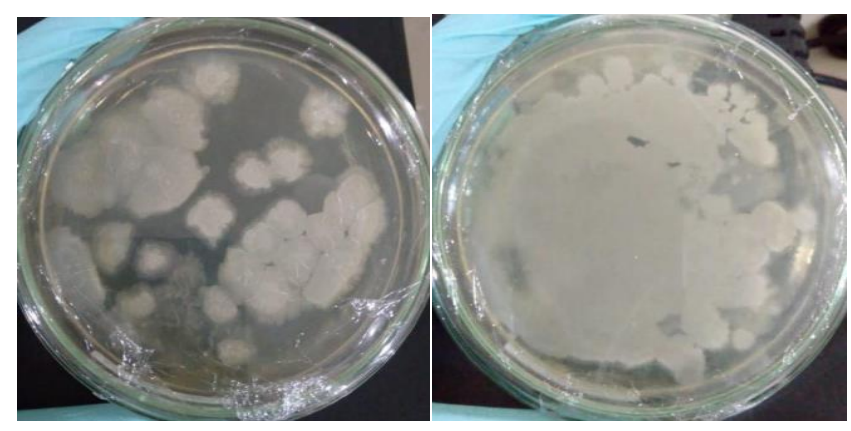

Figure 3. Isolation of bacteria on agar medium

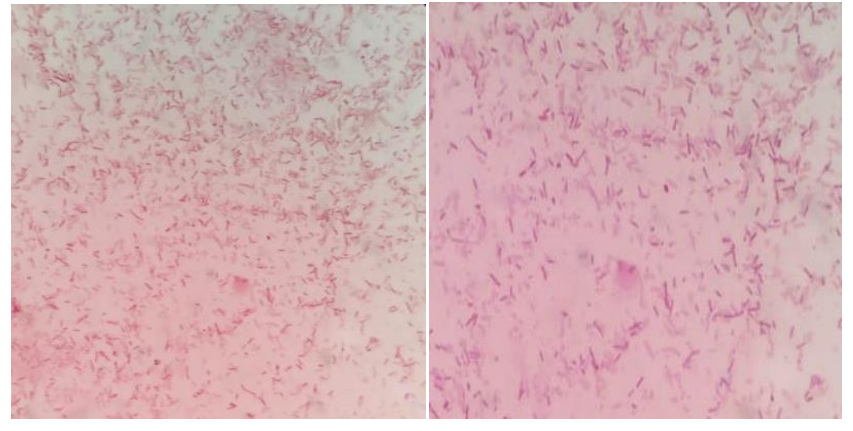

Figure 4. A. Isolate UTMTR VK S7 (Gram-negative), B. UTMTR VK S9 Isolate (Gram-positive)

Table 1. Bacterial macroscopic results

\begin{tabular}{|c|c|c|c|c|}
\hline Isolate & $\begin{array}{c}\text { Colony } \\
\text { form }\end{array}$ & $\begin{array}{c}\text { Colony } \\
\text { edge }\end{array}$ & $\begin{array}{c}\text { Eleva- } \\
\text { tion }\end{array}$ & Color \\
\hline UTMTR VK A1 & Circular & Undulate & Flat & Cream \\
\hline UTMTR VK A2 & Circular & Undulate & Flat & Milk cream \\
\hline UTMTR VK A3 & Irregular & Filamentous & Flat & Cream \\
\hline UTMTR VK A4 & Circular & Entire & Flat & Cream \\
\hline UTMTR VK A5 & Circular & Filamentous & Flat & Cream \\
\hline UTMTR VK A6 & Irregular & Filamentous & Flat & Cream \\
\hline UTMTR VK A7 & Irregular & Filamentous & Flat & Orange cream \\
\hline UTMTR VK A8 & Irregular & Filamentous & Flat & Yellow cream \\
\hline UTMTR VK A9 & Circular & Filamentous & Flat & Milk cream \\
\hline UTMTR VK A10 & Irregular & Filamentous & Flat & Orange cream \\
\hline UTMTR VK S1 & Circular & Entire & Flat & Cream \\
\hline UTMTR VK S2 & Circular & Entire & Flat & Cream \\
\hline UTMTR VK S3 & Circular & Undulate & Flat & Yellow cream \\
\hline UTMTR VK S4 & Irregular & Undulate & Flat & Cream \\
\hline UTMTR VK S5 & Circular & Filamentous & Flat & Cream \\
\hline UTMTR VK S6 & Circular & Undulate & Flat & Cream \\
\hline UTMTR VK S7 & Irregular & Lobate & Flat & Cream \\
\hline UTMTR VK S8 & Irregular & Lobate & Flat & Clear cream \\
\hline UTMTR VK S9 & Circular & Filamentous & Flat & Milk cream \\
\hline UTMTR VK S10 & Circular & Filamentous & Flat & Clear cream \\
\hline
\end{tabular}

Table 2. Bacterial microscopic results

\begin{tabular}{cc}
\hline Isolate & Gram staining result \\
\hline UTMTR VK A1 & Gram (+), rod shaped \\
UTMTR VK A2 & Gram (+), rod shaped \\
UTMTR VK A3 & Gram (+), rod shaped \\
UTMTR VK A4 & Gram (+), rod shaped \\
UTMTR VK A5 & Gram (+), rod shaped \\
UTMTR VK A6 & Gram (+), rod shaped \\
UTMTR VK A7 & Gram (+), rod shaped \\
UTMTR VK A8 & Gram (+), rod shaped \\
UTMTR VK A9 & Gram (+), rod shaped \\
UTMTR VK A10 & Gram (+), rod shaped \\
UTMTR VK S1 & Gram (+), rod shaped \\
UTMTR VK S2 & Gram (+), rod shaped \\
UTMTR VK S3 & Gram (+), rod shaped \\
UTMTR VK S4 & Gram (+), rod shaped \\
UTMTR VK S5 & Gram (+), rod shaped \\
UTMTR VK S6 & Gram (+), rod shaped \\
UTMTR VK S7 & Gram (-), rod shaped \\
UTMTR VK S8 & Gram (-), rod shaped \\
UTMTR VK S9 & Gram (+), rod shaped \\
UTMTR VK S10 & Gram (+), rod shaped \\
\hline
\end{tabular}


Table 3. Biochemical test results

\begin{tabular}{lcccccc}
\hline Isolate & $\begin{array}{c}\mathbf{H}_{2} \text { S } \\
\text { test }\end{array}$ & $\begin{array}{c}\text { Gelatin } \\
\text { test }\end{array}$ & $\begin{array}{c}\text { Catalase } \\
\text { test }\end{array}$ & $\begin{array}{c}\text { Motility } \\
\text { test }\end{array}$ & $\begin{array}{c}\text { Tsia } \\
\text { test }\end{array}$ & $\begin{array}{c}\text { Citrate } \\
\text { test }\end{array}$ \\
\hline UTMTR VK A1 & - & - & - & - & KK & - \\
UTMTR VK A2 & - & - & - & - & KK & - \\
UTMTR VK A3 & - & - & - & - & MK & - \\
UTMTR VK A4 & - & - & - & - & KK & - \\
UTMTR VK A5 & - & - & - & - & KK & - \\
UTMTR VK A6 & - & - & - & - & MK & - \\
UTMTR VK A7 & - & - & - & - & KK & - \\
UTMTR VK A8 & - & - & - & - & MK & - \\
UTMTR VK A9 & - & - & - & - & MK & - \\
UTMTR VK A10 & - & - & - & - & MK & - \\
UTMTR VK S1 & - & - & - & - & MK & - \\
UTMTR VK S2 & - & - & - & - & MK & - \\
UTMTR VK S3 & - & - & - & - & MK & - \\
UTMTR VK S4 & - & - & - & - & KK & - \\
UTMTR VK S5 & - & - & - & - & MK & - \\
UTMTR VK S6 & - & - & - & - & MK & - \\
UTMTR VK S7 & - & - & - & - & MK & - \\
UTMTR VK S8 & - & - & - & - & MK & - \\
UTMTR VK S9 & - & - & - & - & MK & - \\
UTMTR VK S10 & - & - & - & - & MK & - \\
\hline
\end{tabular}

Table 4. Protease enzyme test results

\begin{tabular}{lc}
\hline Isolate & Protease enzyme test result \\
\hline UTMTR VK A1 & + \\
UTMTR VK A2 & + \\
UTMTR VK A3 & + \\
UTMTR VK A4 & + \\
UTMTR VK A5 & + \\
UTMTR VK A6 & + \\
UTMTR VK A7 & + \\
UTMTR VK A8 & + \\
UTMTR VK A9 & + \\
UTMTR VK A10 & + \\
UTMTR VK S1 & + \\
UTMTR VK S2 & + \\
UTMTR VK S3 & + \\
UTMTR VK S4 & + \\
UTMTR VK S5 & + \\
UTMTR VK S6 & + \\
UTMTR VK S7 & + \\
UTMTR VK S8 & - \\
UTMTR VK S9 & + \\
UTMTR VK S10 & + \\
\hline
\end{tabular}

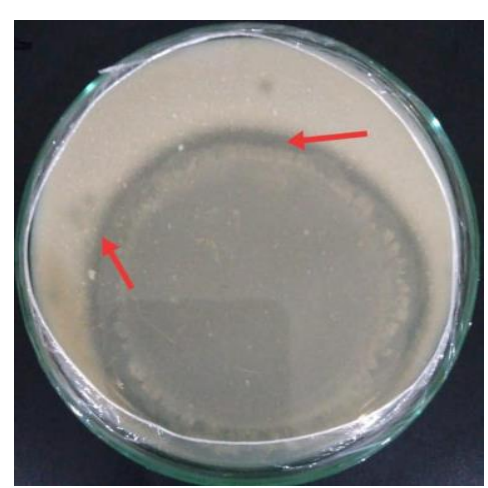

Figure 5. Positive result of enzyme protease (isolate UTMTR VK S9) in skim milk agar medium
The Triple Sugar Iron Agar test in the examination all produced positive results characterized by discoloration. Red color in the medium indicated glucose fermentation but did not produce lactose and sucrose, while the yellow color signified the fermentation of glucose, lactose and sucrose (Baehaki et al. 2019). For sulfide, all isolated negative results were characterized by black color formation in the Triple Sugar Iron Agar medium. This occurred because the medium contained high amounts of amino acids containing sulfur, which reacted to form $\mathrm{H}_{2} \mathrm{~S}$ and also reacted with $\mathrm{Fe}^{2+}$. Therefore, a black FeS color is produced in the medium (Baehaki et al. 2019).

Based on Table 3, the catalase test was negative for all isolates. This test involved the addition of $\mathrm{H}_{2} \mathrm{O}_{2}$ reagents at $3 \%$, when air bubbles $\left(\mathrm{O}_{2}\right)$ formed around the colony indicated a positive result. This was due to the presence of the catalase enzyme which played a role in the degradation of $\mathrm{H}_{2} \mathrm{O}_{2}$ to $\mathrm{O}_{2}$ (Rahmi et al. 2015). The gelatin test results were negative, which signified that the isolate was unable to hydrolyze gelatin. A gelatin positive medium will become mushy or liquid because the gelatin was hydrolyzed (Lay 1994).

\section{Screening of protease enzyme-producing microbes (proteolytic)}

The presence of proteolytic enzymes in the isolate using skim milk medium was tested to ensure that positive results are characterized by the formation of transparent zones around the colony. From 20 isolates examined 19 obtained positive results and only 1 isolate, UTMTR VK S7 was negative (results are shown in Table 4). The existence of proteolytic activity was due to proteolytic enzymes that overhaul proteins in the medium into amino acids and peptides dissolved within. Therefore, there will be clear zones around bacterial colonies. This is because the isolate produces extracellular protease enzymes by forming clear zones around bacterial colonies, as shown in Figure 5 (Djamel et al. 2009; Gupta et al. 2005).

The proteolytic activity of bacteria can be influenced by the nutrient sources used in the medium. In skimmed milk, there are many nutrients such as calcium, casein, magnesium and phosphorus. Therefore, when the nutrients in the medium are lacking, bacteria do not grow optimally within (Nurkasanah 2015).

\section{Activity of enzyme protease}

Isolate bacteria were examined for the presence of proteases by assessing the levels of crude enzymes, enzymes-substrates, hydrolyzed substrates and their respective activities. From the results, isolate UTMTR VK S9 obtained the highest activity of proteases at 23.67 $\mathrm{U} / \mathrm{mL}$. The results of enzyme activity are shown in Figure 6.

Alrumman (2018) stated that the highest protease activity test of $175 \mathrm{U} / \mathrm{mL}$ was obtained in isolate SKF4. Meanwhile, according to Natsir (2015), the highest obtained was $0.394 \mathrm{U} / \mathrm{mL}$ with an incubation time of 36 hours. Enzyme activity is strongly influenced by several factors such as $\mathrm{pH}$, and each enzyme has its own optimum $\mathrm{pH}$ for its proper function (Sumardjo 2006). Enzymes are 
proteins strongly affected by $\mathrm{pH}$, and extremely acidic or alkaline conditions cause denaturation (Dixon 1979). Aside $\mathrm{pH}$, temperature also influences enzyme activity as high temperatures increase kinetic energy. This causes collisions between substrates and enzymes to occur more frequently. However, temperatures that are too high also cause denaturation of enzymes (Sumardjo 2006).

The differences in the results of protease activity in each isolate are likely due to the differences in the type of microorganisms and growth speed in the medium of each isolate. They are also possible due to the differences in the type of enzyme produced. For isolates with low enzyme activity, changes in the structure of enzymes caused a decrease in catalyst rate. Furthermore, due to changes in the active site of the enzyme, it cannot be used to bind the substrate properly (Suleiman et al. 2020).

\section{Molecular identification of protease enzyme-producing bacteria}

The identification of isolated bacteria with the highest activity of proteases was examined using Gene $16 \mathrm{~S}$ rRNA sequence. A gene is a subunit of ribosomes used as a differentiator as well as an evolutionary marker in bacteria. The results of Gene 16S rRNA sequence in isolate UTMTR VK S9 were then compared with GeneBank data in the
BLAST program. From the BLAST program and phylogenetic charts, bacterial species in isolate UTMTR VK S9 have similarities with the bacteria Bacillus paralicheniformis strain A30103. Therefore, isolate UTMTR S9 is Bacillus paralicheniformis strain A30103 (results are shown in Figure 7).

These results correspond with research by Rath (1999) in three hot springs in Odisha, India, where the thermophilic bacteria Bacillus and Pseudomonas produced various types of thermostatic enzymes. Narayan et al. (2008), also sourced from the Savusavu hot spring in Fiji, where the Bacillus sp. was morphologically and molecularly identified. Bacillus protease is very important due to its wide applications such as in the leather industry, pharmaceuticals, food, and waste treatment (Pastor et al. 2001). Bacteria, especially the genus Bacillus is a group that synthesizes protease, due to a very high level of enzyme secretion. Furthermore, Bacillus is also able to synthesize proteins above $20 \mathrm{~g} / \mathrm{L}$. Some Bacillus species synthesize neutral proteases and bases suitable for use in industries. Bacillus can also produce extracellular protease enzymes such as cysteine, serin, and metalloprotease (Contesini et al. 2018).

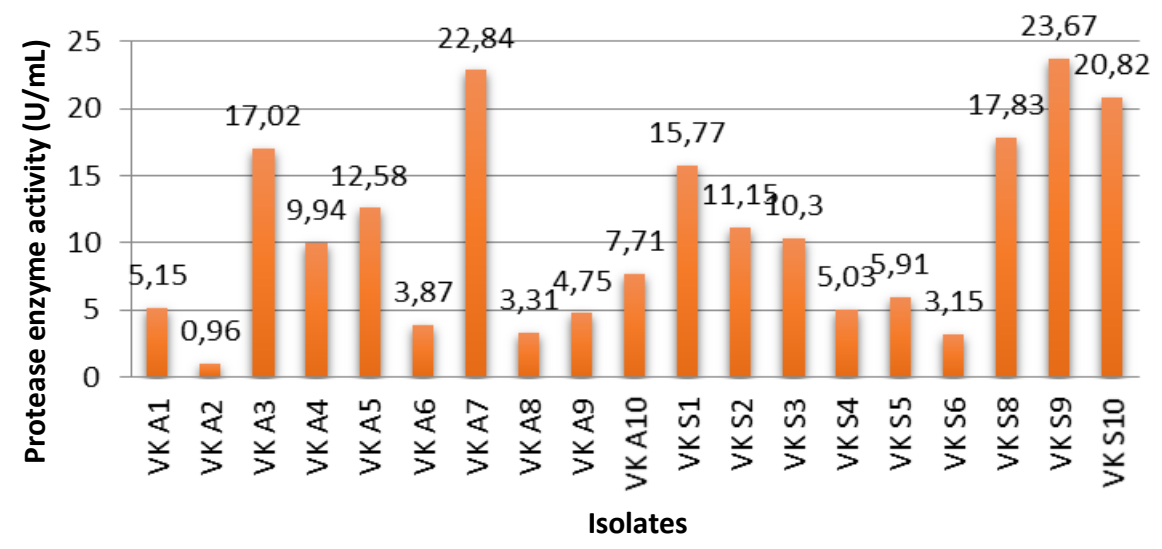

Figure 6. Protease enzyme activity

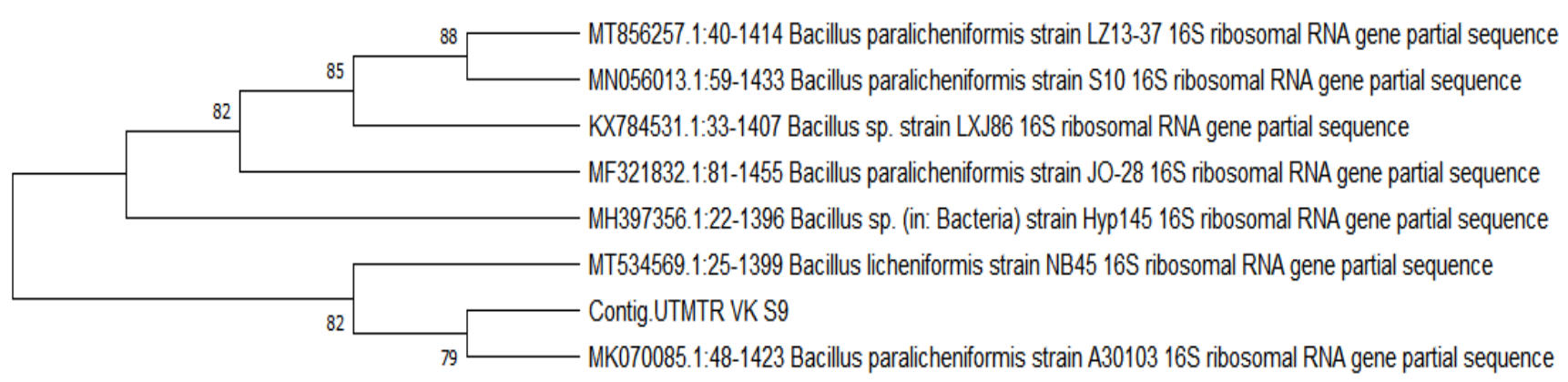

Figure 7. Phylogenetic of isolate UTMTR VK S9 
Therefore, the Bacillus paralicheniformis strain A30103 bacteria can be a producer of protease for industrial use. Based on Dunlap et al. (2015) research, Bacillus paralicheniformis is a Gram-positive bacteria with facultative anaerobic properties, usually having a cream white colony color. These bacteria can hydrolyze urea, aesculin, gelatin, and casein. This signifies that the bacteria are able to use casein as a source of nitrogen (Akhavan Sepahy and Jabalameli 2011; Suleiman et al. 2020). The conditions of Dolok Tinggi Raja Natural Hot Springs, specifically the forests and the activities of wild animals, are suitable for the bacteria Bacillus paralicheniformis A30103 to live and develop. Furthermore, this signifies that the hot springs possess the potential to be utilized for the manufacture of thermophilic protease enzymes.

To conclude, in this study as many as 20 isolates were obtained from sediment and water. These isolates were tested biochemically and morphologically, and 19 possessed the protease enzyme activity. The highest activity was observed in isolate UTMTR VK S9 of 23.67 $\mathrm{U} / \mathrm{mL}$. Molecular identification involved the amplification of 16SrRNA gene based on BLAST and phylogenic analysis with MEGA X. Phylogenic results showed that the isolate UTMTR VK S9 possessed similarities with Bacillus paralicheniformis strain A30103. Further research is required for the addition of research parameters such as optimization of its proteases based on $\mathrm{pH}$, incubation time and temperature, as well as an overview of how the enzyme forms.

\section{ACKNOWLEDGEMENTS}

This study was supported by the Republic of Indonesian Ministry of Research and Technology/National Research and Innovation Agency through Collegiate Research Collaboration Grant between Universitas Prima Indonesia, Medan and Universitas Riau, Pekanbaru, Indonesia with contract number: 222/LLI/PG/2020.

\section{REFERENCES}

Akhavan Sepahy A, Jabalameli L. 2011. 2011. Effect of culture conditions on the production of an extracellular protease by Bacillus sp. isolated from soil sample of Lavizan Jungle Park. Enzym Res. DOI: $10.4061 / 2011 / 219628$

Alrumman S, Mostafa YSM, Al-Qahtani S, Taha THT. 2018. Hydrolytic enzyme production by thermophilic bacteria isolated from Saudi Hot Springs. Open Life Sci 13(1): 470-480. DOI: 10.1515/biol-20180056.

Baehaki A, Nopianti R, Saputra E, Gofar N. 2019. Exploration of protease enzyme producing bacteria from water in tanjung senai swamp Indralaya South Sumatra. In: Herlinda S (eds) Prosiding Seminar Nasional Lahan Suboptimal 2019, Palembang 4-5 September 2019. [Indonesian]

Baltaci MO, Genc B, Arslan S, Adiguzel G, Adiguzel A. 2017. Isolation and characterization of thermophilic bacteria from geothermal areas in Turkey and preliminary research on biotechnologically important enzyme production. Geomicrob J 34 (1): 53-62. DOI 10.1080/01490451.2015.1137662.
Contesini FJ, de Melo RR, Sato HH. 2018. An overview of Bacillus proteases: from production to application. Crit Rev Biotechnol 38 (3): 321-34. DOI: 10.1080/07388551.2017.1354354

Dixon EC, Webb MA. 1979. Enzymes. 3rd ed. Longman, Australia.

Djamel C, Ali T, Nelly C. 2009. Acid protease production by isolated species of Penicillium. Eur J Sci Res 25 (3): 469-477.

Dunlap CA, Kwon SW, Rooney AP, Kim SJ. 2015. Bacillus paralicheniformis sp. Nov., isolated from fermented soybean paste. Intl J Syst Evol Microbiol 65 (10): 3487-3492. DOI: 10.1099/ijsem.0.000441.

Fachrial EDY, Roro R, Satyo J, Lister INE, Anggraini S, Nugroho TT. 2020. Molecular identification of cellulase and protease producing Bacillus tequilensis UTMSA14 isolated from the geothermal hot spring in Lau Sidebuk Debuk, North Sumatra, Indonesia. Biodiversitas 21 (10): 4719-4725. DOI: 10.13057/biodiv/d211035.

Gupta A, Roy I, Patel RK, Singh SP, Khare SK and Gupta MN. 2005. One-step purification and characterization of an alkaline protease from haloalkaliphilic Bacillus sp. J Chromatogr A 1075 (1-2): 103108. DOI: 10.1016/j.chroma.2005.03.127.

Gupta R, Beg Q, Lorenz P. 2002. Bacterial alkaline proteases: molecular approaches and industrial applications. Appl Microbiol Biotechnol 59 (1): 15-32. DOI: 10.1007/s00253-002-0975-y.

Hamdani S, Asstiyani N, Astriany D, Singgih M, Ibrahim S. 2019. Isolation and identification of proteolytic bacteria from pig sludge and protease activity determination. IOP Conf Ser Earth Environ Sci 230 (1): 012095. DOI: 10.1088/1755-1315/230/1/012095.

Hanan S. Alnahdi. 2012. Isolation and screening of extracellular proteases produced by new Isolated Bacillus sp. J Appl Pharm Sci 2 (9): 071074. DOI: DOI: 10.7324/JAPS.2012.2915.

Kumar CG, Takagi H. 1999. Microbial alkaline proteases: from a bioindustrial viewpoint. Biotechnol Adv 17 (7): 561-594. DOI: 10.1016/S0734-9750(99)00027-0.

Kumar S, Stecher G, Li M, Knyaz C, Tamura K. 2018. MEGA X: Molecular Evolutionary Genetics Analysis across computing platforms. Mol Biol Evol 35 (6): 1547-1549. DOI: 10.1093/molbev/msy096.

Lay BW. 1994. Analisis Mikroba di Laboratorium. Rajawali, Jakarta. [Indonesian]

Martins MLL, Nascimento WCA. 2006. Studies on stability of protease from Bacillus sp. and its compatibility with Commercial detergent. $\mathrm{Br}$ Microbiol 37: 307-311. DOI: 10.1088/1755-1315/230/1/012095.

Narayan VV, Hatha MA, Morgan HW, Rao D. 10. 2008.Isolation and characterization of aerobic thermophilic bacteria from Savusavu hot springs in Fiji. Microb Environ 23: 350-352.

Nascimento WC, Martins ML. 2004. Production and properties of an extracellular protease from Bacillus sp. Braz J Microbiol 35 (1-2): 91 96. DOI: 10.1590/S1517-83822004000100015.

Natsir H. 2015. Production of protease enzyme from bacteria in hot spring of South Sulawesi, Bacillus licheniformis Hsa3-1a. J Administrasi dan Kebijakan Kesehatan Indonesia 16 (1): 109364. [Indonesian]

Nurkasanah S. 2015. The effect of different medium content on protease activity Bacillus subtilis. Biotropika J Trop Biol 3 (2): 104-106. [Indonesian]

Pastor MD, Lorda GS, Balatti. 2001. Protease obtention using Bacillus subtilis 3411 and amaranth seed meal medium at different aeration rates. Braz J Microbiol 32 (1): 6-9. DOI: 10.1590/S151783822001000100002

Prescot, Harley, Klein. 1990. Microbiology. $2^{\text {nd }}$ ed. WCB Publisher, England.

Rahmi Y, Darmawi, Mahdi A, Faisal J, Fakhrurrazi, Yudha F. 2015. Identification of Staphylococcus aureus in preputium and vagina of horses (Equus caballus). J Medika Veterinaria 9 (2): 15-158. DOI: 10.21157/j.med.vet..v9i2.3805. [Indonesian]

Rao MB, Tanksale AM, Ghatge MS, Deshpande VV. 1998. Molecular and biotechnological aspects of microbial proteases. Microbiol Mol Biol Rev 62 (3): 597-635.

Rath CC. 1999. Heat stable lipase activity of thermotolerant bacteria from hot springs at Orissa, India. Cytobios 99 (391): 105-111.

Suleiman AD, Abdul Rahman N, Mohd Yusof H, Mohd Shariff F, Yasid NA. 2020. Effect of cultural conditions on protease production by a thermophilic Geobacillus thermoglucosidasius SKF4 isolated from Sungai Klah Hot Spring Park, Malaysia. Molecules 25 (11): 1-14. DOI: $10.3390 /$ molecules25112609. 
Sumardjo, D. 2006. Introduction Chemistry, Book Medical Publishers EGC, Jakarta. [Indonesia]

Tille P. 2013. Bailey \& Scott's Diagnostic Microbiology 13th ed. Mosby/Elsevier, USA.

Uyar F, Porsuk I, Kizil G, Yilma E. 2011. Optimal conditions for production of extracellular protease from newly isolated Bacillus cereus strain CA15. EurAsia J BioSci 5 (1): 1-9. DOI: 10.5053/ejobios.2011.5.0.1

Vermelho AB, Couri S. 2003. Methods to Determine Enzymatic Activity. Bentham Science Publishers, Sharjah, UAE. 